\title{
Unilateral Gynecomastia in a Tennis Player
}

Sang Gue Kang, Woo Jin Song, Chul Han Kim, Ju Won Kim, Min Sung Tark

Department of Plastic and Reconstructive Surgery,

Soonchunhyang University College of Medicine, Seoul, Korea

Correspondence: Sang Gue Kang

Department of Plastic and Reconstructive Surgery, Soonchunhyang University

College of Medicine, 59 Daesagwan-ro, Yongsan-gu, Seoul 140-743, Korea

Tel: +82-2-709-9283, Fax: +82-2-796-3543

E-mail: ksps1108@hanmail.net

This article was presented at the 68th Korean Society of Plastic and Reconstructive Surgeons on Nov 4-7, 2010 in Seoul, Korea.

No potential conflict of interest relevant to this article was reported.

Received: 31 May 2012 • Revised: 16 Jul 2012 • Accepted: 17 Jul 2012 pISSN: 2234-6163・ elSSN: 2234-6171

http://dx.doi.org/10.5999/aps.2012.39.6.675• Arch Plast Surg 2012;39:675-678

Copyright (C) 2012 The Korean Society of Plastic and Reconstructive Surgeons

This is an Open Access article distributed under the terms of the Creative Commons

Attribution Non-Commercial License (http://creativecommons.org/licenses/by-nc/3.0/)

which permits unrestricted non-commercial use, distribution, and reproduction in any

medium, provided the original work is properly cited.

Gynecomastia is a benign enlargement of the male breast due to the proliferation of the glandular component. It may be an incidental finding on routine

Table 1. Endocrinologic findings

\begin{tabular}{lcc|}
\hline Endocrine study & Patients & Normal reference range \\
\hline Beta-hCG $(\mathrm{ng} / \mathrm{mL})$ & 0.00 & $<1.0$ \\
Prolactine $(\mathrm{ng} / \mathrm{mL})$ & 9.87 & $1.8-15.9$ \\
TSH $(\mu \mathrm{ll} / \mathrm{mL})$ & 1.92 & $0.25-4.0$ \\
Free T4 $(\mathrm{ng} / \mathrm{dL})$ & 1.28 & $0.7-2.0$ \\
Testosterone $(\mathrm{ng} / \mathrm{dL})$ & 624.92 & $241-827$ \\
FSH $(\mathrm{mlU} / \mathrm{mL})$ & 4.28 & $1.1-13.5$ \\
LH $(\mathrm{mlU} / \mathrm{mL})$ & 2.65 & $0.4-5.7$ \\
E2 $(\mathrm{pg} / \mathrm{mL})$ & 22.85 & $0-44$ \\
\hline hCG, human chorionic genodotropin; TSH, thyroid-stimulating hormone; Free, T4 \\
free thyroxine; FSH, follicle-stimulating hormone; LH, luteinizing hormone; E2, \\
estradiol.
\end{tabular}


examination or may present as an acute unilateral or bilateral painful tender mass beneath the nippleareolar region or as a progressive painless enlargement of the breast [1]. Cases of unilateral breast enlargement require exclusion of underlying breast neoplasm, although virtually any cause of gynecomastia can present with a unilateral enlargement. To the best of our knowledge, there have been only a few studies on occupation-related gynecomastia. We report a case of unilateral gynecomastia in a young male tennis player.

We report on a 26-year-old male patient who was a tennis player and developed unilateral breast enlargement after puberty. He began to notice unilateral breast enlargement by the age of 18 , and underwent surgery at the age of 26 because there was no spontaneous regression. He had no known familial history or medication history such as anabolic steroid use. There was no discharge from the nipples, tenderness or pain in the nipple-areolar complex. He was a professional tennis player for more than 10 years. His body mass index (BMI) was $21.9 \mathrm{~kg} / \mathrm{m}^{2}$, which was in normal range. Anamnestic information on breast enlargement was elicited from the patient and the age of notable breast enlargement, age of maximal breast enlargement, and breast size changes after playing tennis were noted. Using Simon's classification, with division into four grades, grade IIA gynecomastia of the right breast was noted. Endocrinal function tests were within normal hormonal range (Table 1). He underwent subcutaneous mastectomy under general anesthesia. Through the periareolar incision, glandular tissue was removed by meticulous dissection. After separating the breast parenchyma from the pectoralis major muscle fascia and serratus anterior muscle fascia, we checked the volume of the glandular tissue by measuring its weight, and then sent it out for histologic analysis.

The dissected gland specimen measured $10 \times 5 \times$ $1.5 \mathrm{~cm}$ and weighed $83 \mathrm{~g}$ (Fig. 1). There was no depression on the right breast because $2 \mathrm{~mm}$ thickness fat was preserved under the nipple areolar complex and meticulous dissection was performed. Surgical recovery was uneventful. There were no complications such as seroma, hematoma, abscess, or nipple necrosis. At postoperative 7 months, a clinical evaluation of both breasts showed a symmetrical appearance (Fig. 2 ). The histopathologic findings of the breast mass after reduction showed fibrotic breast tissue with mammary ducts with epithelial hyperplasia, periductal cellular stroma, and stroma hyperplasia, which

Fig. 1.

The dissected specimen measured $10 \times 5 \times 1.5 \mathrm{~cm}$ and weighed $83 \mathrm{~g}$.

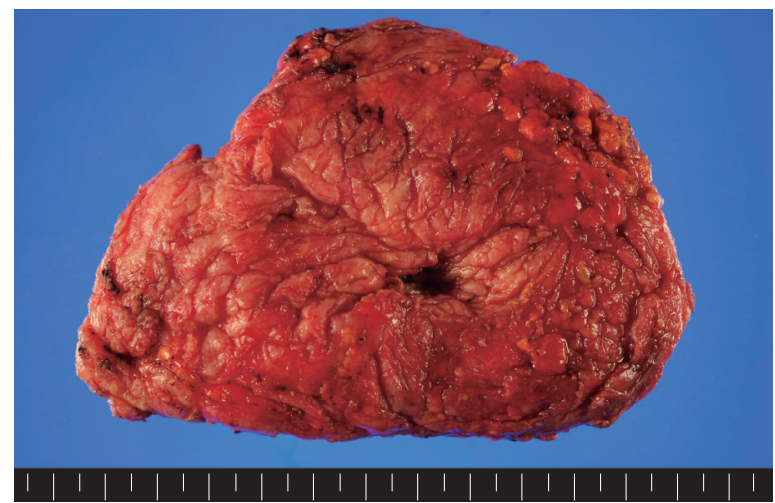

Fig. 2.

(A) Preoperative and (B) postoperative view of the patient 7 months after undergoing right subcutaneous mastectomy.

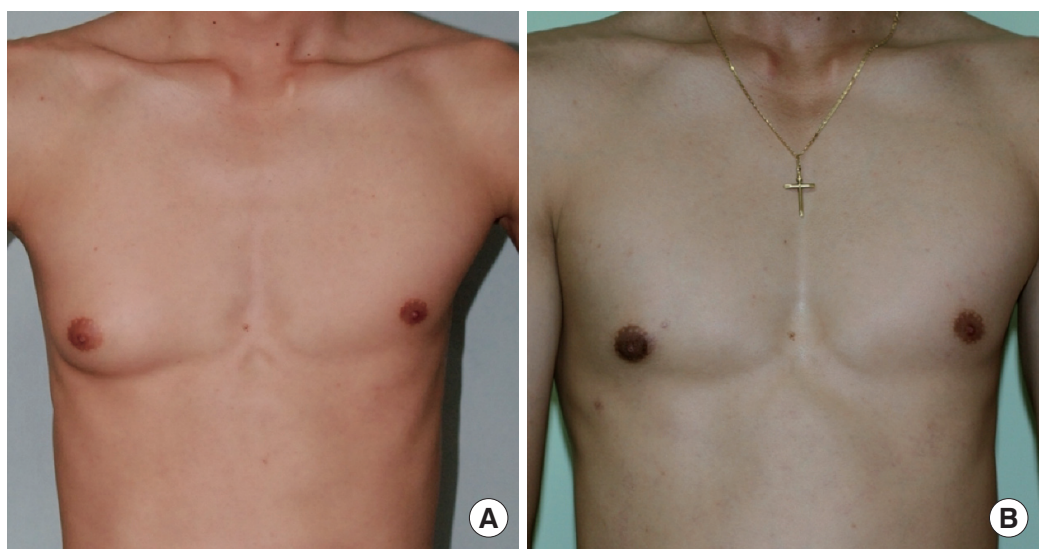



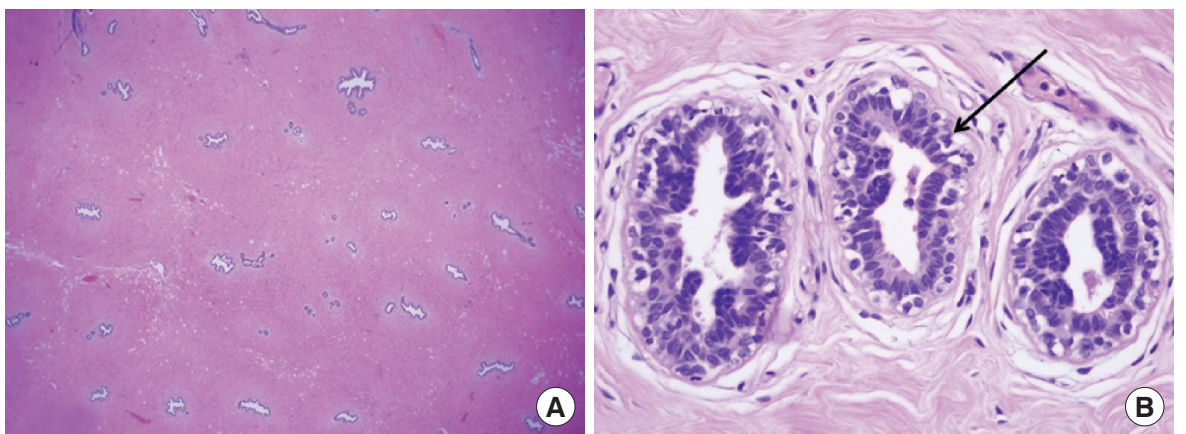

Fig. 3.

Histopathologic findings of gynecomastia. (A) The presence of ducts is noted on the background of the dense fibrous stroma $\left(H \& E_{1} \times 12.5\right)$. (B) The pointed black arrow indicates a duct in the gynecomastia showing typical columnar duct epithelium with scattered basal cells. The nuclei are regular, without visible nucleoli, and without mitoses $\left(H \& E_{1} \times 400\right)$. led to the diagnosis of gynecomastia (Fig. 3).

Gynecomastia is a benign enlargement of the male breasts caused by glandular proliferation, occurring at three distinct peaks according to an age distribution: infancy, adolescence, and old age. On the other hand, pseudogynecomastia is caused by increased fat deposition, and has a higher incidence than true gynecomastia ( $40 \%$ to $60 \%$ ). It is more common in obese patients of old age and usually regresses when they lose weight [2]. Common known causes for breast enlargement include hormonal aberrations, carcinoma, endocrine disease, systemic disorders, and certain drugs [3]. Anthropometric measurements such as BMI may be helpful for diagnosing gynecomastia because obesity can be associated with increased peripheral conversion of androgens to estrogens and is associated with a higher prevalence of gynecomastia [3]. However, our patient was young and non-obese. The histopathologic findings showed an inferiority of fat tissue, and the presence of ductal epithelium, which can be a diagnostic feature of true gynecomastia.

The main pathophysiology of gynecomastia is alteration in the balance between the stimulatory effect of estrogen and the inhibitory effects of androgens on the development of the breast [4]. There are some studies on sports-related unilateral gynecomastia due to anabolic steroids in body builders, which can also lead to a hormonal imbalance [5]. However, we ruled out anabolic steroids because the patient showed normal hormonal status and had not used steroids.

When palpable breast masses are hard, fixed, peripheral to the nipple, and associated with nipple discharge, we should exclude breast neoplasm in unilateral gynecomastia [4]. Our patient was asymptomatic and we excluded malignancy based on the histopathologic diagnosis.

A previous report describes a case of unilateral pseudogynecomastia that developed after working 20 years in a manual metal pressing factory. In that study,
6 cases of unilateral pseudogynecomastia were profession-related and resulted from chronic vibration and pressure [2]. The patients were all obese men of older age, and the histologic findings of their specimens were shown to be fatty tissue only.

The exact mechanism of gynecomastia formation in our case is unclear, but we think pathophysiology of this phenomenon could be similar to the theories of posttraumatic lipoma formation [3]. With reference to this theory, we assumed that continuous exercise, pressure, and vibration may have impacted the patient's axilla and unilateral chest wall while playing and practicing tennis along with primarily holding his tennis racket on one side of his body. Continuous stimulation can cause the local release of growth factors, which are inflammatory mediators over the anterior chest wall muscles. It is supposed that these factors trigger differentiation of precursor cells to new mature glandular proliferation, and in turn, causing the development of gynecomastia.

The evaluation of unilateral gynecomastia can be complex. It should begin with a patient's detailed history, physical examination, and hormonal function test to access the causes and to exclude systemic or neoplastic diseases. Though there are no specific comorbidities associated with gynecomastia, we should consider related causes such as continuous stimulation before concluding the cause is idiopathic. Although the mechanism of such gynecomastia formation is unclear, more cases are needed to perform an advanced examination trial.

\section{References}

1. Braunstein GD. Gynecomastia. N Engl J Med 1993; 328:490-5.

2. Arnon O, Barnea Y, Zaretski A, et al. Occupational pseudogynecomastia: a new etiology for unilateral gynecomastia. Plast Reconstr Surg 2005; 115:1e-4e. 3. Herbert DC, DeGeus J. Post-traumatic lipomas of the 
abdominal wall. Br J Plast Surg 1975;28:303-6.

4. Ersoz H, Onde ME, Terekeci H, et al. Causes of gynaecomastia in young adult males and factors associated with idiopathic gynaecomastia. Int J Androl 2002;25:312-6.

5. Babigian A, Silverman RT. Management of gynecomastia due to use of anabolic steroids in bodybuilders. Plast Reconstr Surg 2001;107:240-2. 